УДК 796:316.48:34

\title{
ХАРАКТЕРИСТИКА СОЦІАЛНИХ КОНФЛІКТІВ У СФЕРІ ФІЗИЧНОЇ КУЛЬТУРИТА СПОРТУ
}

\author{
Марина Саннікова ${ }^{1}$ \\ ${ }^{1}$ Харківська державна академія фізичної культури, м. Харків, Україна, svetlanastadnik87@gmail.com
}

https://doi.org/10.29038/2220-7481-2019-01-22-28

\begin{abstract}
Анотаціï
Актуальність теми дослідження. У будь-яких міжособистісних стосунках нерідко виникають конфліктні ситуації. Сфера фізичної культури та спорту також не $\epsilon$ винятком. В умовах інтенсивної тренувальної й змагальної діяльності неминуче зростають напруженість і конфліктогенність, що зумовлено недостатньою психологічною підготовкою особистості до конструктивної взаємодії. У зв'язку з цим актуалізується значущість наукових досліджень соціальних конфліктів, які виникають у сфері фізичної культури та спорту із погляду комплексного підходу. Мета дослідження - охарактеризувати правову сутність соціальних конфліктів у сфері фізичної культури та спорту. Методи дослідження - аналіз та узагальнення літературних джерел; системний аналіз; математичне моделювання. Результати дослідження. Систематизація наукових досліджень соціальних конфліктів у сфері фізичної культури та спорту дала змогу з'ясувати їхні часові та просторові рамки, охарактеризувати учасників, предмет, об'єкт, стадії розвитку й типи. Розкрито сутність соціальних конфліктів, які можуть мати або не мати юридичний характер. Визначено особливості юридичних конфліктів і їх прояв у сфері фізичної культури та спорту. Побудовано геометричну модель, яка характеризує простір правового регулювання соціальних конфліктів. Висновки. Виявлено, що конфлікти у сфері фізичної культури й спорту належать до соціального типу конфліктів, які характеризуються рамками, учасниками, предметом, об’єктом, стадіями розвитку та типом. 3'ясовано, що в реальній практиці розвитку сфери фізичної культури й спорту простежуємо різні соціальні конфлікти, які мають юридичний характер, а отже, вирішуються з використанням дозволених юридичних засобів та можуть стати предметом розгляду таких юридичних інститутів як, наприклад, спортивний арбітраж. Побудована модель відображає простір правового регулювання соціальних конфліктів, сформована на підставі трьох складників характеристик: «потреби», «можливості розв'язання» й «міри задоволеності», що утворюють три двомірні простори, де діагоналі утворюють систему координат.
\end{abstract}

Ключові слова: соціальні конфлікти, сфера фізичної культури та спорту, простір правового регулювання, геометрична модель.

Марина Санникова. Характеристика социальных конфликтов в сфере физической культуры и спорта. Актуальность темы исследования. В любых межличностных отношениях нередко возникают конфликтные ситуации. Сфера физической культуры и спорта также не является исключением. В условиях интенсивной тренировочной и соревновательной деятельности неизбежно растут напряженность и конфликтогенность, что обусловлено недостаточной психологической подготовкой личности к конструктивному взаимодействию. В связи с этим актуализируется значимость научных исследований социальных конфликтов, которые возникают в сфере физической культуры и спорта с точки зрения комплексного подхода. Цель исследования - охарактеризовать правовую сущность социальных конфликтов в сфере физической культуры и спорта. Методы исследования анализ и обобщение литературных источников; системный анализ; математическое моделирование. Результаты исследования. Систематизация научных исследований социальных конфликтов в сфере физической культуры и спорта позволила выяснить их временные и пространственные рамки, охарактеризовать участников, предмет, объект, стадии развития и типы. Раскрывается сущность социальных конфликтов, которые могут иметь или не иметь юридический характер. Определяются особенности юридических конфликтов и их проявление в сфере физической культуры и спорта. Построена геометрическая модель, которая характеризует пространство правового регулирования социальных конфликтов. Выводы. Выявлено, что конфликты в сфере физической культуры и спорта относятся к социальному типу конфликтов, которые характеризуются рамками, участниками, предметом, объектом, стадиями развития и типом. Установлено, что в реальной практике развития сферы физической культуры и спорта наблюдаются различного рода социальные конфликты, которые имеют юридический характер, а следовательно, решаются с использованием разрешенных юридических средств и могут стать предметом рассмотрения таких юридических институтов как, например, спортивный арбитраж. Построенная модель отражает пространство правового регулирования социальных конфликтов, сформированная на основании трех составляющих характеристик: «потребности», «возможности разрешения» и «меры удовлетворенности», образующие три двухмерные пространства, где диагонали образуют систему координат.

Ключевые слова: социальные конфликты, сфера физической культуры и спорта, пространство правового регулирования, геометрическая модель. 
Marina Sannikova. Characteristic of Social Conflicts in the Field of Physical Culture and Sports. Relevance of the Research Topic. In any interpersonal relationships often arise conflict situations. The field of physical culture and sports is also no exception. In the conditions of intensive training and competitive activity, tension and conflict potential increase. This is due to the lack of psychological preparation of the individual for constructive interaction. In this regard, the importance of scientific research of social conflicts that arise in the field of physical culture and sports with the use of an integrated approach is actualized. The purpose of the research is to characterize the legal nature of social conflicts in the field of physical culture and sports. Methods of research - analysis and synthesis of literary sources; system analysis; math modeling. Results of the Study. Systematization of scientific studies of social conflicts in the field of physical culture and sports allowed to find out their temporal and spatial framework, to characterize the participants, subject, object, stage of development and types. The essence of social conflicts, which may or may not be legal in nature, is disclosed. The features of legal conflicts and their manifestation in the field of physical culture and sports are determined. A geometric model is constructed that characterizes the space of legal regulation of social conflicts. Conclusions. It is revealed that conflicts in the sphere of physical culture and sports are related to the social type of conflicts, which are characterized by frames, participants, object, object, stages of development and type. It has been established that in the real practice of development of the sphere of physical culture and sports there are various kinds of social conflicts that are of a legal nature. They are solved using legal means and may be subject to consideration by such legal institutions as, for example, sports arbitration. The constructed model reflects the space of legal regulation of social conflicts. It is formed on the basis of three component characteristics: «needs», «resolution possibilities» and «satisfaction measures». They form three twodimensional spaces, where the diagonals form a coordinate system.

Key words: social conflicts, the sphere of physical culture and sports, the space of legal regulation, the geometric model.

Вступ. На жаль, конфлікти є реальністю повсякденного життя, зокрема й у сфері фізичної культури та спорту. Соціальні конфлікти завжди викликали інтерес у політиків, економістів, правознавців й в інших фахівців. У середині 90-х років ХХ ст. створено самостійну комплексну науку під назвою «конфліктологія» [3].

Конфліктологія, як і будь-яка інша наука, має тісний міждисциплінарний зв’язок із соціологією та соціальною психологією, педагогікою, історією, політологією, економікою тощо. Однак однією 3 найважливіших суміжних із конфліктологією наук $є$ юридична наука, тому що багато соціальних конфліктів або породжуються юридичними ситуаціями, або протікають у сфері правових відносин. Це й стало причиною виникнення дисципліни, що називається юридичною конфліктологією, предметом якої є вивчення конфліктів, що виникають, розбудовуються й вирішуються в рамках внутрішнього (національного) або міжнародного права [5].

Юридична конфліктологія безпосередньо стосується проблеми розв'язання конфліктів, які виникають у сфері фізичної культури та спорту, яким властиві як загальні риси, характерні для будьякого соціального конфлікту, так і специфічні особливості.

Аналіз останніх досліджень і публікацій засвідчив, що проблеми соціального конфлікту у сфері фізичної культури й спорту постійно перебувають у центрі уваги фахівців. Особливо інтенсивно, на нашу думку, їх вивчення проводили у 80-х pp. ХХ ст. [3; 9; 12]. Разом із тим потреби практики в зазначений період вплинули на визначення дослідницьких позицій і пріоритетів, у результаті чого проблематику соціального конфлікту у сфері фізичної культури та спорту розглядали переважно із психолого-педагогічних позицій. Результатом такого підходу було, зазвичай, вивчення соціального конфлікту у сфері фізичної культури й спорту як взаємодії за перевагою лише конфліктуючих сторін, або як міжособистісного конфлікту, або як проблеми формального та неформального лідерства, соціально-психологічної сумісності й т. ін. [1; 11; 13].

І раніше, і зараз існували й існують соціальні конфлікти у сфері фізичної культури та спорту, які не можуть бути розглянуті й проаналізовані, а тим більше вирішені лише із психолого-педагогічних позицій.

Мета дослідження - охарактеризувати правову сутність соціальних конфліктів у сфері фізичної культури та спорту.

Завдання дослідження: 1) систематизувати сучасні наукові уявлення про соціальні конфлікти у сфері фізичної культури та спорту; 2) побудувати геометричну модель, яка характеризує простір правового регулювання соціальних конфліктів.

Методи дослідження - аналіз та узагальнення літературних джерел; системний аналіз; математичне моделювання.

Результати дослідження. 3'ясовано, що поняття «конфлікт» учені трактують неоднозначно. На нашу думку, найбільш удалим є трактування соціального конфлікту в праці В. В. Кузіна, М. С. Ку- 
тєпова, Д. Г. Холодняка як процесу, у якому два (або більше) індивіди або групи активно шукають можливість перешкодити один одному досягти певної мети, запобігти задоволенню інтересів суперника або змінити його погляди й соціальні позиції [12].

Проведений пошук свідчить, що соціальний конфлікт характеризується рамками, учасниками, предметом, об'єктом, стадіями розвитку та типами. В. Лукашук [13] розглядає просторові, часові й внутрішньосистемні рамки соціального конфлікту. Аналіз учасників соціального конфлікту може здійснюватися 3 погляду різних наук. Із позиції психології Л. О. Котлова соціальний конфлікт розглядається як міжособистісний, тому що його учасниками завжди $є$ люди, починаючи від спору двох фізичних осіб і закінчуючи спором формальних або неформальних малих груп [10]. Із позиції соціології I. 3. Танчин характеризує соціальний конфлікт як конфлікт соціальних громад - соціальних верств населення, класів, державних та інших організацій, масових рухів і т. ін. [16]. Із позиції політології О. Залізко соціальний конфлікт трактує як політичний або геополітичний, тобто як конфлікт на державному або міждержавному рівні [8].

Предмет конфлікту - те основне протиріччя, через яке й заради розв'язання якого суб'єкти вступають у спір: проблема влади, проблема володіння різними цінностями, проблема формального й неформального лідерства, проблема соціально-психологічної сумісності тощо [4]. У праці С. І. Петрова знаходимо, що об'єктом соціального конфлікту завжди є ресурс, матеріальна або духовна цінність, елемент матеріального світу й соціальної реальності, що може служити предметом особистих, групових, суспільних, державних інтересів [15].

На думку науковців $[2 ; 3 ; 4]$, зазвичай виділяють дві основні стадії розвитку соціального конфлікту - латентну (сховану) й відкриту. Латентна стадія включає низку етапів: виникнення об'єктивної конфліктної ситуації; усвідомлення хоча б одним із суб'єктів своїх інтересів у цій ситуації; усвідомлення перешкод для задоволення своїх інтересів; їх усвідомлення, а також відповідних перешкод іншою стороною; конкретні дії однієї зі сторін для відстоювання своїх інтересів; негативна відповідь однієї зі сторін на звернення іншої. Відкрита стадія характеризується наявністю й очевидністю конфлікту для всіх учасників. У цій стадії дії сторін здобувають зовнішню форму. Саме на цій стадії нерідко залучають засоби масової інформації, третіх осіб, що можуть вплинути на конфлікт як щодо сприяння його розвитку, так і щодо подолання суперечностей.

До основних типів соціальних конфліктів В. В. Кузін, М. Є. Кутєпов, Д. Г. Холодняк відносять глобальні й регіональні; ситуаційні та позиційні; групові й міжособистісні; гострі та повільно протікаючі; відновлювальні конфлікти; політичні, економічні, побутові, культурні й соціальні (у вузькому змісті - у сфері праці, охорони здоров'я, соціального забезпечення, освіти тощо) та ін. [12].

В. Лукашук [13] класифікує соціальні конфлікти за такими підставами: кількість учасників, ступінь урегульованості, тривалість, ресурси тощо. Зокрема, соціальні конфлікти у спорті можуть бути поділені на конфлікти в аматорському спорті й конфлікти у професійному спорті. Варто згадати про Олімпійські ігри в 1980 та в 1984 рр. Це і є прикладом соціального конфлікту та характеризується як міжнародний, глобальний, гострий, політичний, тривалий, зі значною кількістю учасників.

Деякі положення, вироблені вітчизняними педагогами й психологами, іманентно містять у собі розгляд деяких аспектів, які з повною на те підставою можуть бути віднесені до проблематики соціального конфлікту у сфері фізичної культури та спорту, що має юридичний характер. Так, Ю. А. Коломейцев виділяс 10 основних груп причин, які можуть викликати конфлікт у сфері фізичної культури й спорту: рівень специфічних якостей; зросто-вагові дані спортсменів; відмінності психофізіологічних характеристик: характерологічні властивості особистості спортсмена; особистісні якості спортсменів; розбіжності з приводу системи цінностей спорту, засобів їх досягнення й т. ін.; специфіка процесу спілкування, міжособистісних контактів і комунікацій; негативні психічні стани; спортивно-виробничі причини; організаційно-управлінські причини; побутові причини [9].

Класифікація, що запропонована, на думку самого автора, далека від своєї повноти. Однак для нас важливо те, що низка з виділених груп причин породжують конфлікти, які можуть мати юридичний характер. До них, передусім, слід віднести конфлікти, що виникають, за термінологією Ю. А. Коломейцева, на спортивно-виробничому, організаційно-управлінському й побутовому грунті.

Як відомо, соціальний конфлікт може мати або не мати юридичний характер. Як вважають А. Я. Анцупов, А. І. Шипілов, юридичним конфліктом потрібно визнати будь-який конфлікт, у якому спір так чи інакше пов'язаний із правовими відносинами сторін (іх юридично значимими діями або станами), а отже, суб' єкти, або мотивація їхньої поведінки, або об'єкт конфлікту мають правові ознаки, а конфлікт спричиняе «юридичні наслідки» [2]. 
Із правового погляду соціальні конфлікти досить неоднорідні. У юридичній сфері вони виникають і розвиваються у зв'язку з об'єктивно наявними суперечностями між декількома правовими нормами, що стосуються того самого предмету. Зміст і значення правових норм визначають дії конфліктуючих сторін у цьому випадку. Соціальні конфлікти поза юридичною сферою набувають юридичних ознак лише в процесі свого розвитку. Соціальні конфлікти змішаного характеру містять як правові, так $\mathrm{i}$ неправові елементи [13].

Юридичний характер соціального конфлікту залежить від його суб’єктів - юридичних чи фізичних осіб. У випадку, коли суб'єктами $є$ конкретні юридичні особи - конфлікт завжди набуває юридичного характеру. Фізична особа як суб'єкт конфлікту стає учасником цивільного, адміністративного процесу як позивач, відповідач, потерпілий, обвинувачуваний, свідок. 3 іншого боку, у низці випадків, юридичний аспект конфлікту є вибірковим, тобто стосується не всіх фізичних осіб, а лише окремих. Більше того сторони, що виступають суперниками, можуть бути нерівнозначними: фізична особа може вступити в конфлікт із юридичною особою й навпаки [6].

Г. Б. Власова стверджує, що важливу роль у соціальному конфлікті, який має юридичний характер, відіграють такі суб'єкти, як посередники й судді. Впливаючи на конфліктуючі сторони своїм авторитетом або іншими засобами, посередники власними діями намагаються запобігти, зупинити, розв'язати конфлікт. Вони допомагають протиборчим сторонам дійти згоди за допомогою переговорів, тому що не наділені владою виносити будь-яке рішення. На відміну від посередників, судді повинні розібратися в причинах й обставинах конфлікту й винести своє рішення [5].

Важливе значення в низці соціальних конфліктів, що мають юридичний характер, із погляду предмету та об'єкта, займають неправильні конфлікти, найважливішим суб'єктом яких стає посередник - фахівець у певній галузі права, здатний роз'яснити ситуацію й дати необхідні поради, що усувають грунт для виникнення або розвитку конфлікту. Неправильні конфлікти простежуємо тоді, коли сторона вважає, що перебуває з іншою стороною у правовідносинах, хоча насправді їх немає, або коли сторона не усвідомлює, що перебуває з іншою стороною у правовідносинах, або коли сторона вважає, що інша сторона діє незаконно, у той час як дії супротивника правомірні, чи коли сторона вважає, що інша сторона діє правомірно, хоча це не відповідає дійсності [7].

Специфічними юридичними підставами для визначення типу соціального конфлікту, що має юридичний характер, є галузь права, до якої може бути віднесений конфлікт (цивільне, адміністративне, трудове, фінансове право тощо); природа правової норми, що стосується конфлікту (що уповноважує, що зобов'язує, що забороняє норми); різновид правозастосовної установи (арбітражний суд, третейський суд і т. ін.) тощо [5].

Розв'язання соціального конфлікту, що має юридичний характер, відповідно до Конституції України - прерогатива судової влади, а саме Конституційного Суду, судів за цивільними, карними, адміністративними та іншими справами. Усе це - державні судові інстанції, що здійснюють розв'язання соціального конфлікту на основі формально регламентованих правових норм. Однак існують соціальні конфлікти, що мають юридичний характер, які найефективніше вирішуються неформальними (квазіюридичними) методами, котрі використовує неформальний арбітраж або третейський (неофіційний) суд.

Деякі автори $[12 ; 14]$ виокремлюють кілька різновидів неформального арбітражу (третейського суду). По-перше, це зобов'язуючий арбітраж, який розглядає спори й виносить остаточне рішення, що має обов'язкову силу для сторін. По-друге, це рекомендаційний арбітраж, який розглядає спори та виносить рішення рекомендаційного характеру. По-третє, це арбітраж «остаточної пропозиції» (різновид зобов'язуючого арбітражу), який розглядає варіанти рішення, запропоновані кожній зі сторін спору й вибирає один із них без унесення будь-яких змін. По-четверте, це обмежений арбітраж (різновид зобов'язуючого арбітражу), який діє під час розгляду спору в певних межах, установлених сторонами до початку розгляду й доведених до відомаарбітрів.

У цьому дослідженні ми вважали за доцільне представити простір правового регулювання соціальних конфліктів, використовуючи геометричні уявлення як більш узагальнювальну мову передачі необхідної інформації про саму природу соціальних конфліктів. Ми виходили 3 того, що будь-які соціальні конфлікти формуються на підставі «потреб», «можливості розв'язання» й «міри задоволеності». Кожна зі складових характеристик є незалежною й у комбінації по дві вони породжують три двомірні простори (далі - одиничний квадрат), у якому діагоналі утворюють систему координат, розгорнуту на $45^{\circ}$. Одна 3 діагоналей $\epsilon$ шкалою виміру міри напруги відповідної узагальнювальної характеристики, а друга відображає варіативність значення відповідної характеристики до напруженості на першій діагоналі. 
Для повної уяви простору правового регулювання поведінки потрібне включення в нього всіх трьох незалежних характеристик. На підставі «потреби», «можливості розв'язання» й «міри задоволеності» можливо скласти повний простір правового регулювання з аналогічним результатом одержання чотирьох шкал - діагоналей, одна 3 яких відображатиме узагальнену характеристику правового регулювання, а інші - варіативність утвору значення відповідного прояву цієї характеристики (рис. 1.).

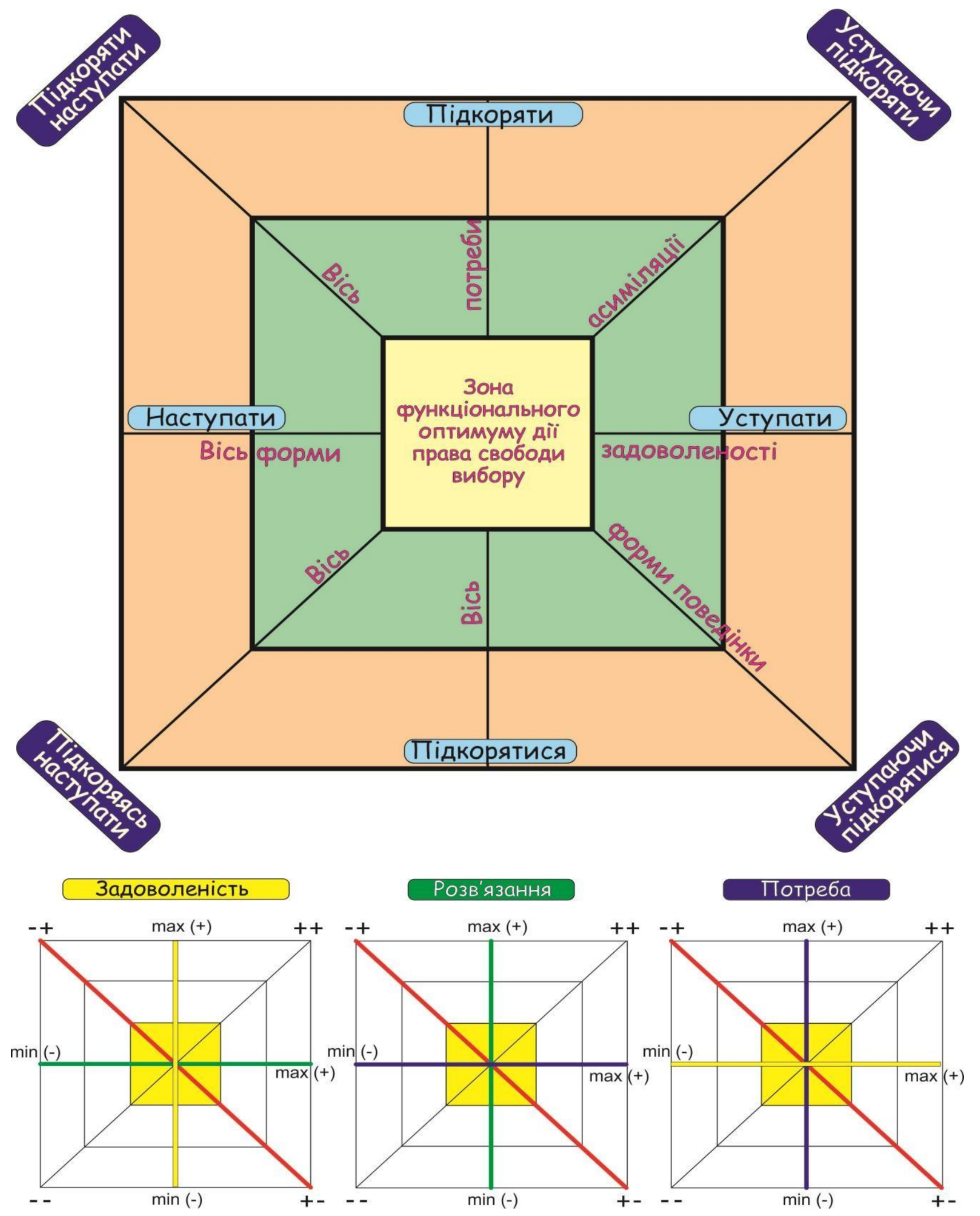

Рис. 1. Простір правового регулювання соџіальних конфліктів 
Як бачимо, всі простори одиничних квадратів розділені на три зони, віддаленість яких від центра координат виміряється в частках сигм. У першій зоні функціонального оптимуму границі віддалені від центра на одну сигму; друга зона - границя, віддалена на дві сигми; третя зона - границя, віддалена на три сигми. У двох одиничних квадратах, що представляють поля правового регулювання поведінки, задіяні всі три формотворні характеристики. Представлення третього поля недоцільне, тому що воно, по-перше, має повну аналогію побудови, а по-друге, грунтується на вже використовуваних трьох незалежних формотворчих характеристиках $\mathrm{i} \epsilon$ похідною частиною простору. Необхідність його використання визначається тим, що із трьох одиничних квадратів, які представляють поля правового регулювання поведінки, побудовані на основі попарної комбінації незалежних формотворчих характеристик: «потреби», «можливості розв'язання» й «міри задоволеності» в організації спільної поведінки - існує два варіанти побудови тривимірного простору для повного вираження всіляких форм, організації взаємозумовлених відносин, що відображають природу виникнення соціальних конфліктів.

Дискусія. Спорт являє собою невід'ємну складову частину життєдіяльності суспільства. Тому конфліктам, що виникають у цій сфері, властиві як загальні риси, характерні для будь-якого соціального конфлікту, так і специфічні особливості. Як і будь-який соціальний конфлікт, конфлікти у сфері фізичної культури та спорту характеризується певними просторовими та часовими рамками, учасниками, предметом, об'єктом, стадіями розвитку й типами $[6,13]$. Однак, як стверджує О. Залізко [8], соціальні конфлікти у сфері спорту можуть мати свою класифікацію.

Досі соціальні конфлікти досліджувалися з погляду різних наук. Із позиції психології - Л. О. Котловою [10], із позиції соціології - І. 3. Танчиним [16], Ю. О. Крохіною [11], із позиції юридичної науки - Г. Б. Власовою [5], М. Ш. Гунібським [7]. Наукова дискусія із досліджуваної проблематики свідчить, що дослідження сутності соціальних конфліктів є складним явищем правової дійсності й потребує подальшого поглибленого вивчення.

Науковий інтерес у літературі викликають також конфлікти й правосуддя у сфері спорту. Поняття та види конфліктів розглядаються В. В. Галкіним [6], О. Залізко [8]. Правову характеристику та систему спортивних арбітражних судів (САC) у міжнародному спортивному русі розглядають Н. В. Міляков [14], В. В. Кузін, М. С. Кутєпов, Д. Г. Холодняк [12], В. Лукашук [13]. Розв'язання міжособистісних конфліктів у спортивній команді досліджувалось H.I. Алексєєвою [1], Holt, N. L., Knight, С. J. \& Zukiwski, P. [18], Kyle F. Paradis, Albert V. Carron \& Luc J. Martin. [19], Hamm-Kerwin, S. \& Doherty, A. [17]. Конфлікти в спорті й соціально-психологічний тренінг як засіб їх розв'язання вивчалися С. І. Петровим [15]. Результати нашого дослідження доповнюють результати наукового пошуку, представлені у вищезазначених працях щодо характеристики соціальних конфліктів у сфері спорту.

Висновки та перспективи подальших досліджень. Виявлено, що конфлікти у сфері фізичної культури та спорту належать до соціального типу конфліктів, які характеризуються рамками, учасниками, предметом, об’єктом, стадіями розвитку й типом.

3'ясовано, що в реальній практиці розвитку сфери фізичної культури та спорту відбуваються різні соціальні конфлікти, які мають юридичний характер, а отже, розв'язуються з використанням дозволених юридичних засобів та можуть стати предметом розгляду таких юридичних інститутів як, наприклад, спортивний арбітраж.

Побудована модель відображає простір правового регулювання соціальних конфліктів, сформована на підставі трьох складових частин характеристик: «потреби», «можливості розв'язання» й «міри задоволеності», що утворюють три двомірні простори, у яких діагоналі утворюють систему координат.

Перспективи подальших досліджень пов’язуємо з необхідністю розгляду нормативно-правового регулювання й досвіду діяльності Міжнародного спортивного арбітражного суду.

\section{Джерела та література}

1. Алексеева Н. И. Разрешение межличностных конфликтов в спортивной команде. Вестник Костромского государственного университета. Серия: Педагогика. Психология. Соииокинетика. 2015. С. 157-159.

2. Анцупов А. Я., Шипилов А. И. Конфликтология: учеб. для вузов. Санкт-Петербург: Питер, 2007. 496 с.

3. Бандурка А. М., Друзь В. А. Конфликтология: учеб. пособие для вузов. Харьков: Ун-т внутр. дел, 1997. $355 \mathrm{c}$.

4. Вишнякова Н. Ф. Конфликтология: учеб. пособие. Минск: Университетское изд-во, 2002. 317 с.

5. Власова Г. Б. Юридическая конфликтология: учеб. пособие. Москва: Феникс, 2016. 251 с.

6. Галкин В. В. Конфликты в спорте. Понятие и виды. Москва: Проспект, 2010. 113 с.

7. Гунибский М. Ш. Юридическая конфликтология: учеб. пособие. Москва: НОРМА, 2017. 547 с.

8. Залізко О. Спортивній спір: поняття і класифікація. Наииональный юридический журнал: теория и практика. 2018. № 3. С. 78-80.

9. Коломейцев Ю. А. Взаимоотношения в спортивной команде. Москва: Физкультура и спорт, 1984. 128 с. 
10. Котлова Л. О. Психологія конфлікту: курс лекцій: навч. посіб. Житомир: Вид-во ЖдУ ім. І. Франка, 2013. $112 \mathrm{c}$.

11. Крохина Ю. А. Методологические основы социологии физической культуры и спорта: учеб. 3-е изд., перераб. и доп. Москва: ЮНИТИ-ДАНА, 2011. 463 с.

12. Кузин В. В., Кутепов М. Е., Холодняк Д. Г. Спортивный арбитраж. Москва: ФОН, 1996. 165 с.

13. Лукащук В. Современный спорт и социальные конфликты. Социология: теория, методы, маркетинг. 2010. №3. С. 185-197.

14. Миляков Н. В. Правовая характеристика и система спортивных арбитражных судов (САС) в международном спортивном движении. Москва: Инфра-М, 2008. 383 с.

15. Петров С. И. Конфликты в спорте и социально-психологический тренинг как средство их разрешения: дис .....канд. психол. наук : 13.00.04. Санкт-Петербург, 2004. 218 с.

16. Танчин I. 3. Соціологія: навч. посіб. для студентів ВНЗ, аспірантів, викладачів. 3-тє вид., переробл. і доповн. Київ: Знання, 2008. 351 с.

17. Hamm-Kerwin S. \& Doherty A.. Intra-groupconflict in non-profit sport boards. Journal of Sport Management. 2010. No. 24. Pp. 245-271.

18. Holt N.L., Knight C.J. \& Zukiwski P. Femaleathletes' perceptions of teammate conflict in sport: Implications for sport psychologyconsultants. The Sport Psychologist. 2012. No. 26. P. 135-154.

19. Kyle F. Paradis, Albert V. Carron \& Luc J. Martin. Athlete perceptions of intra-groupconflict in sport teams. Sport \& Exercise Psychology Review. 2014. Vol. 10 No. 3. P. 4-18.

\section{References}

1. Alekseeva, N. I. (2015). Razreshenie mezhlichnostnyh konfliktov v sportivnoi komandie [Resolving interpersonal conflicts in a sports team]. Vestnik Kostromskogo gosudarstvennogo universiteta. Seriya: Pedagogika. Psihologiya. Sotsiokinetika. 157-159.

2. Antsupov, A. Ya., Shipilov, A. I. (2007). Konfliktologiya [Conflict resolution]: ucheb. dlya vuzov. SPb: Piter, 496.

3. Bandurka, A. M., Druz', V. A. (1997). Konfliktologiya [Conflict resolution]: uchiebnoe posobie dlia vuzov. Har`kov: Un-t vnutr. del, 355.

4. Vishniakova, N. F. (2002). Konfliktologiya [Conflict resolution]: uchebnoe posobie. Minsk: Universitetskoe, 317.

5. Vlasova, G. B. (2016). Yuridicheskaya konfliktologiya [Legal Conflict resolution]: uchebnoe posobie. Moskva: Feniks. 251.

6. Galkin, V. V. (2010). Konflikty v sportie. Poniatiye i vidy [Conflicts in sports. Concept and types] M.: Prospekt, 113.

7. Gunibskiy, M. Sh. (2017). Yuridicheskaya konfliktologiya [Legal Conflictology]: uchebnoe posobie. Moskva: NORMA. 547.

8. Zalizko O. (2018). Sportyvnii spir: poniattia i klasyfikatsiia [Sports Dispute: Concept and Classification]. Natsionalnyiy yuridicheskiy zhurnal: teoriya i praktika, no. 3, 78-80.

9. Kolomeytsev, Yu. A. (1984). Vzaimootnosheniya v sportivnoy komande [Relationships in a sports team]. M.: Fizkultura i sport, 128.

10. Kotlova, L. O. (2013). Psykholohiia konfliktu [Psychology of Conflict]: kurs lektsii: navchalnyi posibnyk. Zhytomyr: Vyd-vo ZhDU im. I. Franka, 112.

11. Krohina, Yu. A. (2011). Metodologicheskie osnovy sotsiologii fizicheskoy kulturyi i sporta [Methodological foundations of the sociology of physical culture and sports]: uchebnik. 3-e izd., pererab. i dop. M.: YuNITIDANA, 463.

12. Kuzin, V. V., Kutepov, M. E., Holodnyak D. G. (1996). Sportivnyi arbitrazh [Sports Arbitration] M.: FON, 165.

13. Lukaschuk, V. (2010). Sovremennyiy sport i sotsialnyie konfliktyi [Modern sports and social conflicts]. Sotsiologiya: teoriya, metody, marketing, no.3, 185-197.

14. Milyakov, N. V. (2008). Pravovaya harakteristika i sistema sportivnyih arbitrazhnyih sudov (SAS) v mezhdunarodnom sportivnom dvizhenii. [Legal characteristic and system of sports arbitration courts (SAS) in the international sports movement]. M.: Infra-M, 383.

15. Petrov, S. I. (2004). Konfliktyi v sporte i sotsialno-psihologicheskiy trening kak sredstvo ih razresheniya [Conflicts in sports and socio-psychological training as a means of resolving them]: dis kand. psihol. nauk : 13.00.04: $\mathrm{SPb} .218$.

16. Tanchyn, I. Z. (2008). Sotsiolohiia [Sociology]: navch. posib. dlia studentiv VNZ, aspirantiv, vykladachiv. 3-tie vyd., pererob. i dop. Kyiv: Znannia, 351.

17. Hamm-Kerwin, S. \& Doherty, A. (2010). Intra-group conflict in non-profit sport boards. Journal of Sport Management, no. 24, 245-271.

18. Holt, N.L., Knight, C.J. \& Zukiwski P. (2012). Femaleathletes' perceptions of teammate conflict in sport: Implications for sport psychologyconsultants. The Sport Psychologistm, no. 26, 135-154.

19. Kyle, F. Paradis, Albert, V. Carron, \& Luc, J. Martin. (2014). Athlete perceptions of intra-group conflict in sport teams // Sport \& Exercise Psychology Review. Vol. 10, no. 3,4-18.

Стаття надійшла до редакції 22.02.2019 р. 